\begin{tabular}{l|l|l}
\hline Bentham open & The Open Dentistry Journal & $\begin{array}{l}\text { The } \\
\text { Open Dentisty } \\
\text { lournal }\end{array}$ \\
\hline CrossMark & Content list available at: www.benthamopen.com/TODENTJ/ & DOI: $10.2174 / 1874210601610010158$ \\
\hline
\end{tabular}

\title{
Editorial
}

\section{Editorial: Natural Products in Oral Health}

Oral health is a state of being free from chronic mouth and facial pain, oral and throat cancer, oral sores, birth defects such as cleft lip and palate, periodontal (gum) disease, tooth decay and tooth loss, and other diseases and disorders that affect the oral cavity [1]. This definition by the World Health Organization, though not comprehensive or exhaustive, gives us the gamut of oral health. However, dental caries and periodontal disease steal the limelight under the umbrella of oral health [2]. Most governments which spend significant amounts on health concentrate on the control of dental caries followed by periodontal disease [1]. Though preventive measures and control of risk factors form the major form of public health intervention, there is a definite role for pharmaceutical or active agents in management of oral health. One of the limitations identified in the wide array of active agents on oral diseases has been their exclusive focus on targeting pathogenic organisms. However, the host plays a very significant role in the occurrence of diseases. Identification of other agents especially from natural products has become exciting due to the possibility of addressing host issues as well as pathogenic organisms. Traditional medicines of various origins focus on the use of natural products in various forms to bring equilibrium to the disturbed human body and thus eliminating the 'toxins' responsible for the ailments $[3,4]$. This time tested intervention for diseases though not always scientifically verified opens to us a large window of opportunity for managing the present day illnesses.

Periodontal diseases which primarily include gingivitis and periodontitis are caused by the bacterial biofilm but mediated and modified by the host [5]. Studies on natural products for periodontal diseases have led to commercially available medication especially for gingivitis $[5,6]$. Natural products have many properties which can have an effect on the immune and inflammatory process during disease progression apart from inhibiting pathogenic bacteria [7, 8].

Developments in drug delivery including nanoforms open up myriad opportunities for developing therapies including locally deliverable agents against periodontal diseases $[5,9]$.

Dental caries is a bacterial initiated demineralization of the hard tissue structures of the tooth. Plant based extracts and their derivatives have been explored for the anti-cariogenic effects $[10,11]$. New research has shown the potential of natural products in remineralising tooth surfaces affected by dental caries [12]. The potential of local sustained delivery of active agents for protecting tooth surface is also being explored [13].

The other important potential for the use of natural products is in oral mucosal diseases. Effect of plant based products on oral mucositis including as a result of cancer therapies has been an important focus of research [14]. The polyphenols from plant based products have been very effective for their anti-inflammatory and healing effects [15]. Nanotechnology has helped in the sustained delivery as well in maintaining a higher bioavailability of the active drug [16].

The special issue on natural products and oral health will create more interest among the researchers and clinicians to view naturally derived therapies as an effective way to manage oral diseases.

Commercial exploration towards better patient utilization of these therapies based on natural products should be promoted. Nanotechnology for better formulation of drugs will definitely give the much needed boost towards these goals. 


\section{REFERENCES}

[1] Kapoor V. Achieving global oral health: Aim of all... Indian J Dent 2015; 6(4): 165-6. [http://dx.doi.org/10.4103/0975-962X.170365] [PMID: 4691983]

[2] Service SG of the USPH. Oral Health in America: A Report of the Surgeon General 2000

[3] Torwane NA, Hongal S, Goel P, Chandrashekar BR. Role of Ayurveda in management of oral health. Pharmacogn Rev 2014; 8(15): 16-21. [http://dx.doi.org/10.4103/0973-7847.125518] [PMID: 24600192]

[4] Surathu N, Kurumathur AV. Traditional therapies in the management of periodontal disease in India and China. Periodontol 2000 2011; 56(1): 14-24.

[http://dx.doi.org/10.1111/j.1600-0757.2010.00369.x] [PMID: 21501235]

[5] Pulikkotil SJ, Nath S. Effects of curcumin on crevicular levels of IL-1 $\beta$ and CCL28 in experimental gingivitis. Aust Dent J 2015; 60(3): $317-27$. [http://dx.doi.org/10.1111/adj.12340] [PMID: 26219195]

[6] Pulikkotil SJ, Nath S. Effect on interleukin-1 $\beta$ and interleukin-8 levels following use of fibrin sealant for periodontal surgery. Aust Dent J 2014; 59(2): 156-64. [http://dx.doi.org/10.1111/adj.12178] [PMID: 24861389]

[7] Pimentel SP, Barrella GE, Casarin RC, et al. Protective effect of topical Cordia verbenacea in a rat periodontitis model: immuneinflammatory, antibacterial and morphometric assays. BMC Complement Altern Med 2012; 12: 224. [http://dx.doi.org/10.1186/1472-6882-12-224] [PMID: 23171319]

[8] Palaska I, Papathanasiou E, Theoharides TC. Use of polyphenols in periodontal inflammation. Eur J Pharmacol 2013; 720(1-3): 77-83. [http://dx.doi.org/10.1016/j.ejphar.2013.10.047] [PMID: 24184667]

[9] Akhtar F, Rizvi MM, Kar SK. Oral delivery of curcumin bound to chitosan nanoparticles cured Plasmodium yoelii infected mice. Biotechnol Adv 2012; 30(1): 310-20. [http://dx.doi.org/10.1016/j.biotechadv.2011.05.009] [PMID: 21619927]

[10] Hambire CU, Jawade R, Patil A, Wani VR, Kulkarni AA, Nehete PB. Comparing the antiplaque efficacy of 0.5\% Camellia sinensis extract, $0.05 \%$ sodium fluoride, and $0.2 \%$ chlorhexidine gluconate mouthwash in children. J Int Soc Prev Community Dent 2015; 5(3): 218-26. [http://dx.doi.org/10.4103/2231-0762.158016] [PMID: 26236682]

[11] Ferrazzano GF, Amato I, Ingenito A, Zarrelli A, Pinto G, Pollio A. Plant polyphenols and their anti-cariogenic properties: a review. Molecules $2011 ; 16(2): 1486-507$.

[http://dx.doi.org/10.3390/molecules16021486] [PMID: 21317840]

[12] He L, Deng D, Zhou X, et al. Novel tea polyphenol-modified calcium phosphate nanoparticle and its remineralization potential. J Biomed Mater Res B Appl Biomater 2015; 103(8): 1525-31. [http://dx.doi.org/10.1002/jbm.b.33333] [PMID: 25470574]

[13] Franca JR, De Luca MP, Ribeiro TG, et al. Propolis-based chitosan varnish: drug delivery, controlled release and antimicrobial activity against oral pathogen bacteria. BMC Complement Altern Med 2014; 14: 478. [http://dx.doi.org/10.1186/1472-6882-14-478] [PMID: 25495921]

[14] Aghamohamamdi A, Hosseinimehr SJ. Natural products for management of oral mucositis induced by radiotherapy and chemotherapy. Integr Cancer Ther 2016; 15(1): 60-8.

[http://dx.doi.org/10.1177/1534735415596570] [PMID: 26306626]

[15] Varoni EM, Lodi G, Sardella A, Carrassi A, Iriti M. Plant polyphenols and oral health: old phytochemicals for new fields. Curr Med Chem 2012; 19(11): 1706-20. [http://dx.doi.org/10.2174/092986712799945012] [PMID: 22376030]

[16] Shakeri A, Sahebkar A. Nanotechnology: A successful approach to improve oral bioavailability of phytochemicals. Recent Pat Drug Deliv Formul 2016; 10(1): 4-6.

[http://dx.doi.org/10.2174/1872211309666150611120724] [PMID: 26063398]

Pulikkotil Shaju Jacob

Department of Restorative Dentistry International Medical University

Bukit Jalil - 57000 Kuala Lumpur Malaysia

Email: Shaju_Jacob@imu.edu.my

(C) Pulikkotil Shaju Jacob; Licensee Bentham Open.

This is an open access article licensed under the terms of the Creative Commons Attribution-Non-Commercial 4.0 International Public License (CC BY-NC 4.0) (https://creativecommons.org/licenses/by-nc/4.0/legalcode), which permits unrestricted, non-commercial use, distribution and reproduction in any medium, provided the work is properly cited. 